A Klinik für Handchirurgie, Rhön-Klinikum AG, Bad Neustadt an der Saale1, a Semmelweis Egyetem, Rácz Károly Doktori Iskola² és a Semmelweis Egyetem, Általános Orvostudományi Kar, Ortopédiai Klinika, Budapest ${ }^{3}$ közleménye

\title{
A kéztő avascularis csontnekrózisainak diagnosztikája, klasszifikációi és konzervatív terápiája Irodalmi áttekintés
}

\author{
DR. KASZAP BALÁZS ${ }^{1,2}$, DR. SKALICZKI GÁBOR ${ }^{3}$
}

\section{ÖSSZEFOGLALÁS}

A kéztő avascularis csontnekrózisainak diagnosztikája során a röntgen, CT és az MRI felvételek kiértékelésekor - ha létezik egyáltalán radiológiai klasszifikáció a vizsgált kéztőcsontra - megállapítjuk a betegség stádiumát, ami a helyes terápia kiválasztásában nyújthat segítséget. A kizárólagos konzervatív terápiának a legtöbb szerző szerint csak a betegség kezdeti stádiumaiban van létjogosultsága, és az esetleges progreszszió miatt ilyenkor is rendszeres radiológiai kontroll szükséges. A jelen írás a betegség diagnosztikáján és radiológiai klasszifikációin túl a konzervatív terápiás lehetőségeket foglalja össze.

\section{Kulcsszavak: $\quad$ Csontnekrózis; Csukló; Diagnózis; Differenciáldiagnózis;} Kéztő; Klasszifikáció;

B. Kaszap, G. Skaliczki: Avascular necrosis of the carpal bones: diagnostics, classifications and conservative treatment. Review of the literature

The main imaging diagnostic tools for avascular carpal bone necrosis are X-ray, CT and MRI. Radiological classification systems, if one exists for the particular carpal bone at all, can be used as a solid fundament for the therapeutic decision. According to most authors, the exclusive conservative therapy might be useful only in the early stage of the disease, and regular radiological controls have to exclude a progression. The present article introduces the imaging diagnostics, classification systems and conservative therapeutic options of the disease.

Keywords: $\quad$ Carpal bones - diagnostic imaging/Pathology; Diagnosis, differential;

Osteonecrosis - Classification/Diagnostic imaging/Therapy;

Wrist joint - Classification/Diagnostic imaging/Therapy; 


\section{BEVEZETÉS}

A betegség epidemiológiáját, etiológiáját, és természetes lefolyását „A kéztő avascularis csontnekrózisainak kialakulása" című írásban tárgyaltuk (10), a rendelkezésre álló mútéti terápiás opciókkal külön írás foglalkozik majd. Jelen közleményünkben a kéztő avascularis csontnekrózisainak diagnosztikájával, klasszifikációjával és konzervatív kezelési lehetőségeivel foglalkozunk.

Primer avascularis nekrózisnál az etiológiából adódóan a panaszok kialakulását nem kell traumának megelőznie, mégis sok beteg valamilyen sérülésre vagy a kéz megerőltetésére vezeti azt vissza. A fájdalom általában jól lokalizálható (például m. Preiser-nél a radiocarpalis régió radiális oldalán) és palpatióval provokálható. Kezdeti panasz lehet a kéz „fáradékonysága” is. Az idővel növekvő fájdalmat a kéz erejének csökkenése és az ízületi mozgástartomány beszúkülése kísérheti. Több publikációban megjegyzik, hogy milyen nagy különbség lehet az egyes betegek panaszainak intenzitása közt nagyjából azonos radiológiai megjelenés esetén. Van Leeuwen tanulmányában a holdascsont nekrózisának radiológiai manifesztációjához csupán az esetek 63\%-ában társultak tünetek (22).

\section{KÉPALKOTÓ DIAGNOSZTIKA}

A képalkotó diagnosztika alapja a röntgenvizsgálat, ami viszonylag korán a spongiosa sclerosisát és finom cisztás elváltozását mutathatja. Előrehaladottabb stádiumokban a csont kontúrváltozása (törése), esetleg az arthrosis egyéb jelei is láthatók (21). Bizonyos képletek (pl. hamulus ossis hamati vagy borsócsont) a standard kétirányú csukló-felvételeken nem látszanak jól, gyanú esetén speciális felvétel lehet szükséges ( $p l$. carpalis alagút felvétel).

A CT nem a primer diagnosztika eszköze. Segít elkülöníteni a még ép szerkezetű csontot a nekrózis miatt megroppanttól, emellett jobban felmérhető vele a spongiosa sclerosisa és a csontok egymáshoz képesti térbeli viszonya is, amelyből a kéztő stabilitására következtethetünk. Az os lunatum nekrózisánál leírták, hogy ha a röntgent valamiért CT-nek kell követnie, akkor a radiológiai stádiumbesorolás a CT eredménye miatt az esetek 60\%-ában súlyosbodik (19).

Az MRI-lelet már a betegség korai stádiumaiban pozitív, amikor még semmilyen elváltozás nem látható a röntgen-, illetve a CT felvételeken. Ezért gyanú esetén (jellemzően sérülés nélkül jelentkező spontán fájdalomnál) minél gyorsabban érdemes elvégezni ezt a vizsgálatot, például az első negatív röntgenfelvételt követő legfeljebb 3. hónapban, amennyiben a panaszok időközben nem múlnak el. Az MRIvizsgálat során a csontvelősejtek jeléből következtetni lehet a csontanyagcserére. Avascularis nekrózis gyanúja esetén gadolínium alapú kontrasztanyag (KA) i.v. alkalmazása képet ad a csontszövet perfúziójáról és vitalitásáról. Schmitt ehhez a következő szekvenciák alkalmazását javasolja:

- T2 (vagy a megjelenésében hasonló PD) zsírelnyomott

- T1 - natív (KA-adás előtt)

- T1 - zsírelnyomott (KA adása után; a zsírelnyomott technikának köszönhetően csak a kontrasztanyag „világít" a képen, a zsír nem).

A szerző ilyen módon három patológiás csontvelői mintázatot különít el. ( $\uparrow=$ jelerősödés, $\downarrow$ =jelcsökkenés a normálishoz képest; lásd még: 1-2. ábrák) $(19,21)$.

- „N típus” (normál): T2 sötét, T1 világos, sehol sincs fokozott kontrasztanyagfelvétel.

- „A típus” (diffúz ödéma és hipervaszkularizáció): Általában a teljes csontot érintő homogén elváltozás. T2个, T1 $\downarrow$. KA-felvétel a csont minden területén, ami hipervaszkularizációra utal.

- „B típus” („részleges nekrózis” azaz nekrózis és párhuzamosan zajló reparáció): T2个 és T1 $\downarrow$ a nekrotikus zónában, illetve a szöveti reparáció helyén. KA-felvétel csak az épp zajló szöveti reparáció helyén történik, a nekrotikus rész nem reagál. Ennél a típusnál általában három zóna különül el sávosan egymástól: a nekrotikus (általában proximalisan), a reparációs (általában középen) és a vitális zóna (általában distalisan található). Az elkülönülés gyakran legjobban a sagittalis képeken látható. 
- „C típus” (teljes nekrózis): T2 mindenütt sötét. T1 $\downarrow$ az elhalt csontállomány helyén. KA felvétel sehol sem történik.

Ezek a kategóriák nem a betegség spontán lefolyásának kronológiai állomásait jelentik. Arról, hogy milyen a típusok közötti átjárás (mely típusból mennyi idő alatt hány százalékban milyen típus lesz), egyelőre nem áll rendelkezésre elegendő információ. A tapasztalat azt mutatja, hogy az "A" típus gyakran nyom nélkül regenerálódik, de progrediálhat is. $A$ „B" típus olykor idővel „C" típusúvá válik, míg a "C" típus logikusan sosem változik. A klasszifikációt eredetileg a holdascsontra írta le a szerző, de elvileg más kéztőcsontokra is alkalmazható lehet.

\begin{tabular}{|c|c|c|c|}
\hline & T2/PD (fs) & T1 (natív) & $T 1$ (fs) + KA \\
\hline Normál & $\begin{array}{l}\text { A spongiosaállomány } \\
\text { csontvelősejtjei jelszegények, } \\
\text { ödéma nem mutatkozik }\end{array}$ & $\begin{array}{l}\text { A spongiosaállomány magas } \\
\text { zsírtartalmú csontvelősejtjei erős } \\
\text { jelet adnak }\end{array}$ & $\begin{array}{c}\text { A zsírelnyomott technika miatt a } \\
\text { csontvelősejtek a magas } \\
\text { zsírtartalmuk ellenére } \\
\text { jelszegények. Sehol sincs } \\
\text { megnövekedett KA-felvétel }\end{array}$ \\
\hline A típus & Ödéma miatti diffúz jelerősödés & $\begin{array}{l}\text { Az ischaemia és az ödéma a } \\
\text { magas zsírtartalmú csontvelői } \\
\text { sejteket károsítja, a jelerősség } \\
\text { ezzel párhuzamosan mindenhol } \\
\text { csökken }\end{array}$ & $\begin{array}{l}\text { Aktiválódnak az osteoblastok és } \\
\text { osteoclastok, illetve } \\
\text { hipervaszkularizáció lép fel. A } \\
\text { teljes csont területén megnő a } \\
\text { KA-felvétel }\end{array}$ \\
\hline B típus & $\begin{array}{l}\text { A reparációs zóna (középső sáv) } \\
\text { erős jele általában áttevődik a } \\
\text { nekrotikus zónára (proximalis } \\
\text { pólus) is, míg a vitális zóna } \\
\text { (distalis pólus) normál jelet ad }\end{array}$ & $\begin{array}{l}\text { A proximalis pólus } \\
\text { csontvelősejtjei elhaltak, nem } \\
\text { adnak már zsírjelet. A reparatív } \\
\text { zóna gyógyulása kétesélyes, a } \\
\text { zóna nem ad zsírjelet. A vitális } \\
\text { zóna normál jelet ad, de gyakran } \\
\text { alig látható ilyen rész }\end{array}$ & $\begin{array}{l}\text { A proxmialis pólus elhalt, a } \\
\text { distalis elhelyezkedésú vitális } \\
\text { zóna érintetlen: mindkét állapot } \\
\text { alacsony lokális KA-felvételt } \\
\text { eredményez. Egyedül a reparatív } \\
\text { zóna mutat megnövekedett KA- } \\
\text { felvételt }\end{array}$ \\
\hline C típus & $\begin{array}{l}\text { Reparációs zóna nincs, a } \\
\text { proximalis elhelyezkedésű } \\
\text { nekrotikus zóna pedig már } \\
\text { általában ödémamentes } \\
\text { (kivételes esetben megmaradhat } \\
\text { némi ödéma) }\end{array}$ & $\begin{array}{l}\text { A proximalis pólus (és esetleg a } \\
\text { korábbi reparatív zóna egy része) } \\
\text { elhalt: e területek sötétek. Az ép } \\
\text { területek világosak, de kiterjedt } \\
\text { elhalás esetén akár teljesen } \\
\text { hiányozhatnak }\end{array}$ & $\begin{array}{c}\text { A „B” típushoz képest itt hiányzik } \\
\text { a reparációs zóna, így } \\
\text { megnövekedett lokális } \\
\text { KA-felvétel sincs. Mindenhol } \\
\text { alacsony a KA-felvétel }\end{array}$ \\
\hline
\end{tabular}

\section{1. ábra}

A Schmitt szerinti perfúziós típusok MRI-megjelenéseinek sematikus ábrázolása Kienböck kór esetén. Magyarázat a rövidítésekhez: „T2/PD (fs)" = T2 vagy Proton Denzitás súlyozású felvétel zsírelnyomásos technikával (angolul "fat saturated”, „fs"), kontrasztanyag nélkül; "T1 (nativ)”= T1 súlyozású felvétel kontrasztanyag és zsírelnyomásos technika felhasználása nélkül; „T1 (fs) + KA” = zsírelnyomásos T1 súlyozású felvétel kontrasztanyag i.v. adása után (19, 21). 


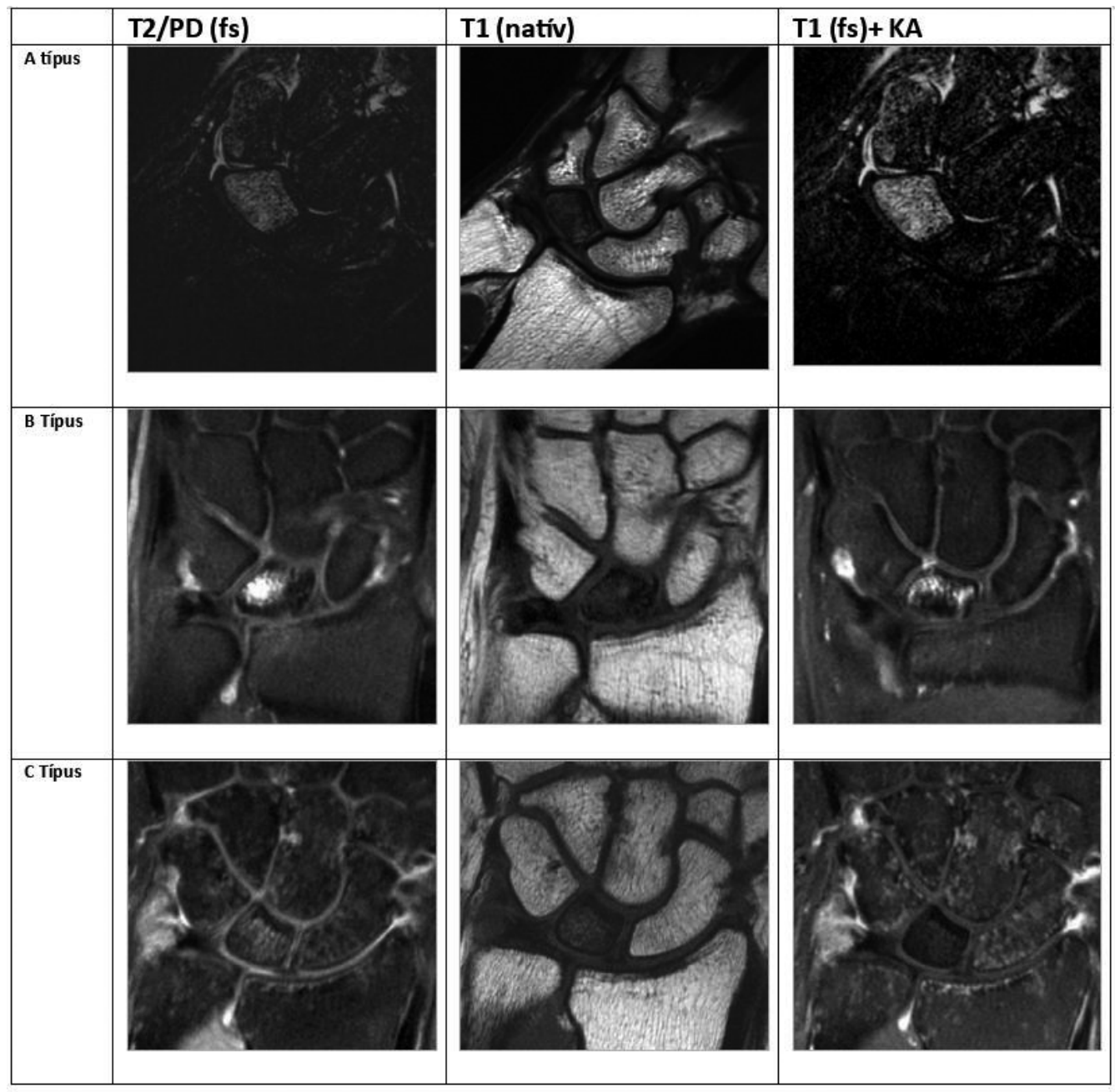

2. ábra

A holdascsont patológiás perfúziós típusainak Schmitt szerinti osztályozása MRI-megjelenés alapján. Magyarázat a rövidítésekhez: lásd az 1. ábra képaláírásánál. Képanyag a Thieme Verlag engedélyével (19).

Az ultrahang nem alkalmas a betegség kimutatására. A szcintigráfia és a SPECT ugyan kumulációs gócot mutat avascularis csontnekrózis esetén, de nem tartoznak a betegség klasszikus képalkotó diagnosztikai eszközei közé $(6,15,17,18)$.
A diagnosztikus artroszkópia porclaesio gyanúja esetén akár önmagában is indikált lehet, gyakran végzik a kézen végzett egyéb mútét kiegészítéseként ( $\mathrm{pl}$ a mútét további lefolyását meghatározó kezdeti lépésként) (1). 


\section{DIFFERENCIÁLDIAGNOSZTIKA}

A már a csontnekrózis kialakulása előtt jelen lévő arthrosis esetén anélkül látjuk egymás mellett a két patológiás állapotot, hogy a csontnekrózis stádiuma feltétlenül előrehaladott lenne. Az intraossealis ganglion élesen elhatárolódó folyadéktartalma (olykor azért egy perifokális ödéma elmoshatja a határt), szklerotikus széle és gyakran egy az ízülettel kapcsolatot tartó csatornácska CT-képe alapján jól elkülöníthető (19). A kéztőcsont contusiójánál (angolul „,bone bruise”), vagy okkult törésénél az MRI ödémát mutat, de a röntgenen és a CT-n törés nem látható. Csonttörés esetén a röntgenen vagy a CT-n legtöbbször jól látható a törésvonal, és az MRI ödémát mutat körülötte. Infekció elkülönítésében a klinikai tünetek segítenek sokat, a jó és rosszindulatú daganatok esetében pedig a daganatra specifikus radiológiai megjelenés. Ritkán differenciáldiagnosztikai problémát okozhatnak a kéztőcsontok fibrocartilaginaris koalíciói vagy a synoviát érintő megbetegedések (pl. reumatoid arthritis) (19).

\section{RADIOLÓGIAI KLASSZIFIKÁCIÓ}

A kéztő minden csontjára vonatkozó, általánosan használható klasszifikáció nem létezik.

A legismertebb klasszifikáció a holdascsont nekrózisának besorolását szolgálja, és Lichtman nevét viseli (3. ábra):

- I: Nincs röntgenelváltozás (általában " $\mathrm{A}^{\prime}$ típusú MRI-megjelenés besorolása Schmitt szerint)

- II: A röntgenen a spongiosa sclerosisa látható (általában „B" típusú MRI-megjelenés Schmitt szerint)

- III-A: A holdascsont megroppanása látható a röntgenen, illetve CT-n. A csont ezáltal helyenként veszíthet a magasságából („lunatum kollapszus”), de ez még nem okozza a kéztőcsontok egymáshoz képesti elmozdulását. (általában „B” vagy „C" típusú MRI-megjelenés Schmitt szerint)

- III-B: A kéztőcsontok patológiás elmozdulása, a kéztő fiziológiás statikája felborul (úgynevezett „carpalis kollapszus”). Jel- lemző a sajkacsont patológiás flexiója, az RS-szög (a radius és az os scaphoideum hossztengelyei által bezárt szög) $>60^{\circ}$.

- III-C: A holdascsont coronalis síkú hasadásos törése (angolul „split fracture”); még revaszkularizációs mútét után is kimondottan rosszul gyógyuló típus. ( $\mathrm{A}, \mathrm{III}-\mathrm{C}$ " Lichtman utólagos kiegészítése 2010-ből, (12) még nem terjedt el egységesen az irodalomban.)

- IV: A holdascsont nekrózisát már arthrosis kíséri a kéztőben.

A III-A és III-B stádium elkülönítése általában hagyományos röntgenfelvétel alapján is lehetséges, ebben a Ståhl-féle magassági index segíthet: ez a longitudinalis és sagittalis holdascsont-átmérő hányadosa; a <0,5 érték patológiásnak számít (23).

A Lichtman féle II stádium MRI lelet szerinti szubklasszifikációja Sowa-tól származik (3):

- $\underline{\text { II-A: }}$ T1 $\downarrow$ (fokális), T2个 (fokális)

- $\quad \underline{\text { I-B }}: \mathrm{T} 1 \downarrow$ (fokális), T2 $\downarrow$ (fokális)

- $\underline{\text { II-C: }}$ T1 $\downarrow$ (generalizált), T2个 (generalizált)

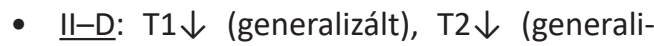
zált)

A sajkacsont avascularis nekrózisának klaszszifikációja Herbert és Lanzetta szerint röntgenfelvétel (és részben szcintigráfia) alapján (6):

- I: röntgen normál, szcintigráfia pozitív

- II: a proximalis pólus sclerotikus, általános osteoporosis jelei mutatkoznak

- III: a proximalis pólus fragmentációja vagy patológiás törése

- IV: carpalis kollapszus, radiocarpalis arthrosis

Ezt a klasszifikációt Kalainov módosította röntgenfelvétel (és részben MRI) alapján (8):

- I: röntgen normál, MRI pozitív

- II: a sajkacsont sclerosisa, helyenként denzitáscsökkenése, fissurák

- III: a sajkacsont fragmentációja

- IV: a sajkacsont kollapszusa, körülötte arthrosis jelei láthatók 
Kalainov egy másik tanulmányban MRI felvételek alapján két csoportra osztotta a Preiser-kóros eseteket (8):

- 1 : diffúz ischaemia (foltokban T1 $\downarrow$, és T2个/izointenz) és/vagy nekrózis (T1 $\downarrow$ és $\mathrm{T} 2 \downarrow)$ jelenléte a sajkacsontban

- II: körülírt elváltozás (általában a csont $<50 \%$-át érinti); ez a jobb prognózisú csoport

Schmitt a Preiser-kórnál a következő stádiumbeosztást javasolta (20):

- I (kezdeti stádium): a röntgenkontúr megtartott, esetleg proximalis osteosclerosis a CT-n, az MRI patológiás eltérést mutat (T2个 fokális csontvelőödéma miatt és emelkedett KA-felvétel)

- II (elörehaladott): a proximalis sclerosis kiterjed; (főleg) proximalis kontúrvesztés, illetve csontfragmentáció („nipple sign”, magyarul kb. „mellbimbó jel”), esetleg egyetlen patológiás törés. Ha elkülöníthető egy patológiás törés, akkor a törésvonal általában tengelyirányú, esetleg ferde és keresztülhalad a sclerotikus részen; a törés csontlemezhez közeli és avulsiós törésre hasonlíthat. Ezzel szemben a traumás töréseknél és proximalis álízületeknél a lefutás általában a csont tengelyére merőleges, és kikerüli az esetleg degeneratív elváltozásként jelenlévő sclerotikus részeket.

- III (végső stádium): a röntgen és CT a csont nagy részén megnövekedett denzitást mutat, az MRI képeken avitális csont képe látszik, nincs KA-felvétel.
A fejescsont nem avascularis nekrózisának deszkriptív röntgenklasszifikációját Milliez alkotta meg (16). Ez nem stádiumbesorolás, nem is köthető terápiás ajánlás hozzá $(7,18)$.

A Milliez-féle klasszifikáció:

- I: a proximalis pólus érintett

- $\underline{1-A}$ : dóm alakú centrális laesio

- I-B: a fej és a nyak érintettsége

- $\underline{\mathrm{I} C \mathrm{C}}$ : a radialis-proximalis rész érintettsége

- II: a distalis rész (a test) érintett

- III: a teljes csont érintett.

A további kéztőcsontok avascularis nekrózisa oly ritka, hogy nem található rájuk vonatkozó radiológiai klasszifikáció az irodalomban.

Egyedül a holdascsont nekrózisának létezik artroszkópos klasszifikációja: Bain az ízületi következmények (porclaesio) által érintett ízfelszínek száma alapján állapítja meg a stádiumbeosztást (4. ábra):

- I: egyetlen ízfelszín érintettsége (a holdascsont radiocarpalis ízfelszínén)

- II: két ízfelszín érintettsége

- II-A: a radiolunaris ízület mindkét ízfelszínén

- II-B: a holdascsont töredezése által porclaesio alakul ki annak mind proximalis, mind distalis ízfelszínén

- III: három ízfelszín érintettsége (a radiolunaris ízület mindkét ízfelszínén, valamint a holdascsont mediocarpalis ízfelszínén)

- IV: négy ízfelszín érintettsége (porclaesio a radiolunaris és a capitolunaris ízület mindkét ízfelszínén) (1). 

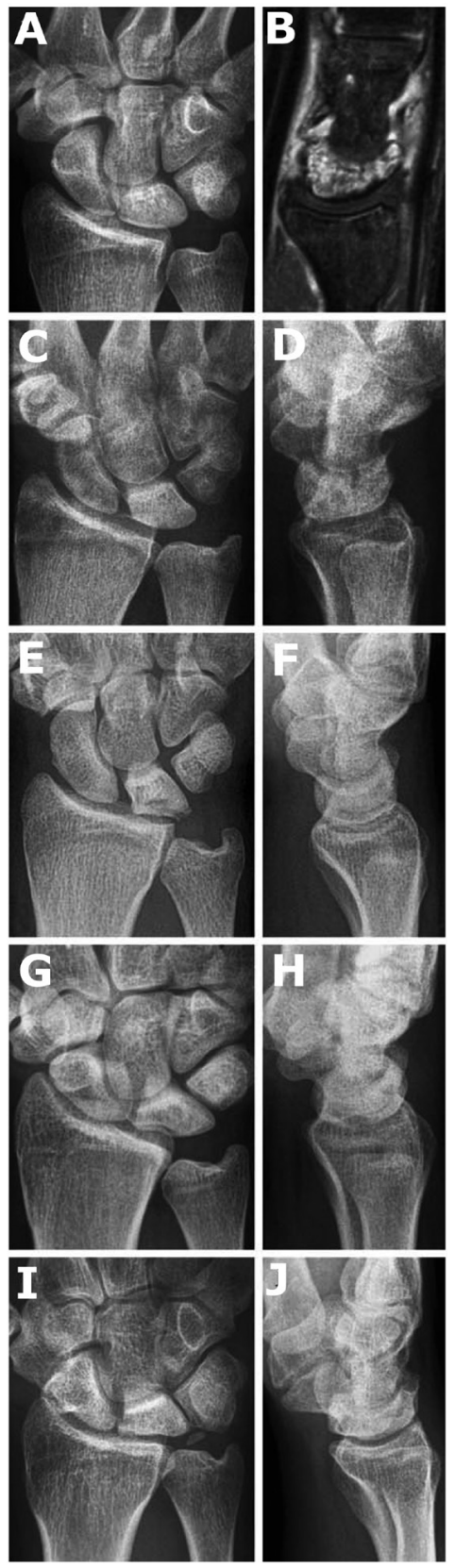

\section{3. ábra}

A holdascsont nekrózisának Lichtman szerinti stádiumai. I. stádiumban a röntgenfelvétel (A) nem mutat eltérést, az MRT felvétel (B) viszont már igen (itt egy zsírelnyomott T1 szekvenciájú kép látható KA adása után sagittalis síkban: a holdascsont KA-t vesz fel). II. stádiumban a röntgenfelvételek (C és D) a holdascsont belső szerkezetének sclerotikus elváltozását mutatják. III-A stádiumban a röntgenfelvételek (E és F) a holdascsont törését mutatják, de a csont magasságcsökkenése csak kis területre korlátozódik, és még nem von maga után carpalis kollapszust. III-B stádiumban (G és H) a holdascsont magasságcsökkenése kiterjedt és carpalis kollapszust idéz elő. IV stádiumban (I és J) már arthrosis jelei is láthatóak. Képanyag a Thieme Verlag engedélyével (19). 


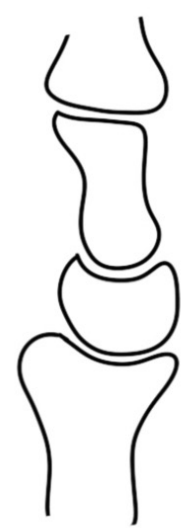

0

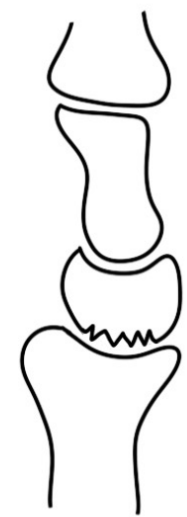

1

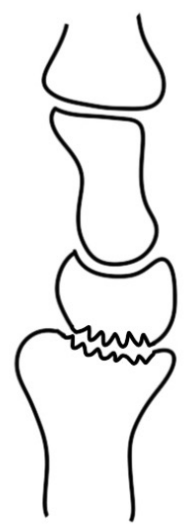

$2 a$

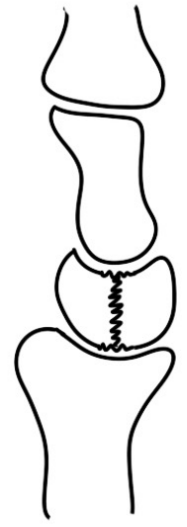

$2 b$

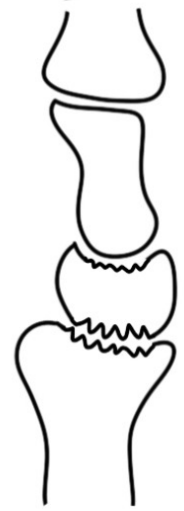

3

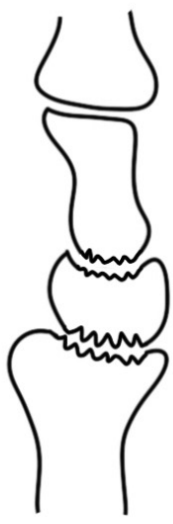

4

4. ábra

A Bain szerinti artroszkópos klasszifikáció m. Kienböck esetén

\section{KONZERVATÍV TERÁPIÁS LEHETŐSÉGEK}

A kéztő valamennyi csontnekrózisánál a kezdeti stádiumban létjogosultsága van a konzervatív terápiának, de nincs egységesnek mondható terápiás ajánlás. A terápia része lehet a csukló terhelésének csökkentése, különböző külső stabilizálás (gipszkötés/sín, ortézis), fájdalomcsillapító (pl. NSAID) alkalmazása. A gyógytorna a mozgástartomány visszanyerésében, illetve az izomtömeg helyreállításában segíthet mútétet vagy hosszas immobilizációt követően. Lökéshullám-terápiát (ESWT) és magasnyomású oxigénterápiát is alkalmaztak már, de az alkalmazásuk nem terjedt el $(4,5)$.

Kezdeti stádiumú Kienböck kórnál Betz és munkatársai csak a szimptomatikus esetekben ajánlanak kezelést (2). Lichtman és munkatársai csak kezdeti stádiumban (Licthman „I-II", Schmitt „A", Bain „0") látják értelmét a konzervatív terápiának (14). Serdülőkorban jó, gyermekkorban (13-15 éves korig) pedig még jobb a holdascsont revascularisatiós potenciálja: ilyenkor kezdetben mindenképpen konzervatív terápia javasolt (legalább 6 hét gipsz, a terápia meghosszabbítása ezután a kontrasztanyagos MRI-kontroll eredményétől függ) (9).

Lenoir 2012-ben az addigi összes dokumentált Preiser kóros esetet $(n=126)$ összegyújtve megállapította, hogy a leggyakrabban alkalmazott terápia a konzervatív volt (32\%) (12). Lauder egy 2006-os metaanalízis során 31 konzervatív terápiás eset eredményeit kiértékelve a többség progresszióját állapította meg (29 eset) (11). Lenoir csak a már amúgy is előrehaladott betegség esetén mútét előtti tüneti kezelésre tartja hasznosnak konzervativ terápiát (12).

Az egyéb kéztőcsontok avascularis nekrózisánál alkalmazott konzervatív terápiára vonatkozóan jóval kevesebb eredmény van a szakirodalomban, ezért terápiás javaslat nem adható.

A konzervatív terápiával sok esetben nem lehet a betegség progresszióját feltartóztatni. Hogy a progresszió időben kiderüljön, rendszeres kontrollvizsgálatok szükségesek. Ennek fő eszköze a betegségek korai stádiumaiban a kontrasztanyagos MRI, később (a csontlemez törése és a kéztő statikájának felbomlása idején) a röntgen és szükség esetén a CT. A kontrollvizsgálatok intervalluma individuális, kezdetben a 6-8 hetes időköz sem túlzó.

\section{ÖSSZEGZÉS}

A kéztő avascularis csontnekrózisainak diagnosztikája föleg a röntgenre (esetleg a CTre) és az MRI-re alapul. Terápiás szempontból a legtöbb lehetőségünk a betegség kezdeti stádiumában van. Ilyenkor a diagnosztika 
szempontjából az MRI áll az előtérben, amellyel az érintett csont belsejében lezajló folyamatok jól leképezhetők; ennek feltétele a spongisából származó jel képződésének az áttekintő ismerete. A jelen írásban bemutatott klasszifikációs rendszerek a terápiás döntést szolgálják, később pedig az eredmény monitorozásában segítenek. Ha a konzervatív terápiát választjuk, fel kell készülni a progresszió lehetőségére, és bekövetkeztekor késlekedés nélkül fel kell állítani a megfelelő mútéti indikációt. A mútéti terápiás opciókról hamarosan külön összefoglaló számol be.

\section{Köszönetnyilvánítás}

A cikk képi anyaga (2-3. ábrák) Prof. Dr. med. Rainer Schmittnek, a Rhön Klinik in Bad Neustadt an der Saale radiológusának a gyűjteményéből származik, köszönet neki és a képek tulajdonosi jogait birtokló Thieme Verlag kiadónak a szíves rendelkezésre bocsátásért.

\section{IRODALOM}

1. Bain G. I., Begg M.: Arthroscopic assessment and classification of Kienbock's disease. Tech Hand Up Extrem Surg. 2006. 10. (1): 8-13. https://doi.org/10.1097/00130911-200603000-00003

2. Betz C., Mehling I. M., Sauerbier M.: Knochennekrosen der Hand. Z. Orthop. Unfall. 2015. 153. (4): 441-454; quiz 455-446. https://doi.org/10.1055/s-0035-1546236

3. Cooney W. P. The Wrist: Diagnosis and Operative Treatment: Wolters Kluwer Health; 2011.

4. D'Agostino C., Romeo P., Amelio E., Sansone V.: Effectiveness of ESWT in the treatment of Kienbock's disease. Ultrasound Med. Biol. 2011. 37. (9): 1452-1456. https://doi.org/10.1016/j.ultrasmedbio.2011.06.003

5. Figueira P. J., Alpuim Costa D., Barbagallo N., Guerreiro F. G.: Stage III Kienbock's disease treated with hyperbaric oxygen: the role of an unusual approach to a rare condition. BMJ Case Rep. 2018. Oct 12. 2018:bcr2018226090 https://doi.org/10.1136/bcr-2018-226090

6. Herbert T. J., Lanzetta M.: Idiopathic avascular necrosis of the scaphoid. J. Hand Surg. Br. 1994. 19. (2): 174-182. https://doi.org/10.1136/bcr-2018-226090

7. Humphrey C. S., Izadi K. D., Esposito P. W.: Case reports: osteonecrosis of the capitate: a pediatric case report. Clin. Orthop. Relat. Res. 2006. 447. 256-259. https://doi.org/10.1097/01.blo.0000203459.12759.29

8. Kalainov D. M., Cohen M. S., Hendrix R. W., Sweet S., Culp R. W., Osterman A. L.: Preiser's disease: identification of two patterns. J. Hand Surg. Am. 2003. 28. (5): 767-778. https://doi.org/10.1016/S0363-5023(03)00260-0

9. Kalb K., Pillukat T., Schmitt R., Prommersberger K. J.: Die Lunatumnekrose im Kindes- und Jugendalter. Handchir. Mikrochir. Plast. Chir. 2010. 42. (3): 187-197. https://doi.org/10.1055/s-0030-1249684

10. Kaszap B., Skaliczki G.: A kéztő avascularis csontnekrózisainak kialakulása. Irodalmi áttekintés. Magyar Traumatológia Ortopédia Kézsebészet Plasztikai Sebészet. 2019. 62. (1-2): 89-95. https://doi.org/10.21755/MT0.2019.062.0102.007

11. Lauder A. J., Trumble T. E.: Idiopathic avascular necrosis of the scaphoid: Preiser's disease. Hand Clin. 2006. 22. (4): 475484. https://doi.org/10.1016/i.hcl.2006.07.005

12. Lenoir H., Coulet B., Lazerges C., Mares O., Croutzet P., Chammas M.: Idiopathic avascular necrosis of the scaphoid: 10 new cases and a review of the literature. Indications for Preiser's disease. Orthop. Traumatol. Surg. Res. 2012. 98. (4): $390-397$. https://doi.org/10.1016/i.otsr.2011.11.013

13. Lichtman D. M., Lesley N. E., Simmons S. P.: The classification and treatment of Kienbock's disease: the state of the art and a look at the future. J. Hand Surg. Eur. Vol. 2010. 35. (7): 549-554. https://doi.org/10.1177/1753193410374690

14. Lichtman D. M., Pientka W. F., 2nd, Bain G. I.: Kienbock disease: Moving forward. J. Hand Surg. Am. 2016. 41. (5): 630-638. https://doi.org/10.1016/i.jhsa.2016.02.013

15. Lutsky K., Beredjiklian P. K.: Kienbock disease. J. Hand Surg. Am. $2012 . \quad 37$. (9): $1942-1952$. https://doi.org/10.1016/i.jhsa.2012.06.029

16. Milliez P. Y., Kinh Kha H., Allieu Y., Thomine J. M.: Ostéonécrose aseptique essentielle du grand os. Revue de la littérature à propos de 3 nouveaux cas. Int. Orthop. 1991. 15. (2): 85-94. https://doi.org/10.1007/BF00179703

17. Peters S. J., Verstappen C., Degreef I., Smet L. D.: Avascular necrosis of the hamate: three cases and review of the literature. J. Wrist Surg. 2014. 3. (4): 269-274. https://doi.org/10.1055/s-0034-1394135

18. Peters S. J., Degreef I., De Smet L.: Avascular necrosis of the capitate: report of six cases and review of the literature. J. Hand Surg. Eur. Vol. 2015. 40. (5): 520-525. https://doi.org/10.1177/1753193414524876

19. Schmitt R., Kalb K.: Imaging in Kienböck's Disease. Handchir. Mikrochir. Plast. Chir. 2010. 42. (3): $162-170$. https://doi.org/10.1055/s-0030-1253433

20. Schmitt R., Frohner S., van Schoonhoven J., Lanz U., Golles A.: Idiopathic osteonecrosis of the scaphoid (Preiser's disease) - MRI gives new insights into etiology and pathology. Eur. J. Radiol. 2011. 77. (2): $228-234$. https://doi.org/10.1016/i.ejrad.2010.11.009

21. Schmitt R.: Karpale Osteonekrosen. Osteologie. 2016. 25. (03): 156-166. https://doi.org/10.1055/s-0037-1619015 
22. van Leeuwen W. F., Janssen S. J., ter Meulen D. P., Ring D.: What is the radiographic prevalence of incidental Kienbock disease? Clin. Orthop. Relat. Res. 2016. 474. (3): 808-813. https://doi.org/10.1007/s11999-015-4541-1

23. Waldt S., Eiber M., Wörtler K.: Messverfahren und Klassifikationen in der muskuloskelettalen Radiologie. Stuttgart, New York: Georg Thieme Verlag; 2017. https://doi.org/10.1055/b-004-140285

\section{Dr. Kaszap Balázs}

Klinik für Handchirurgie, Rhön-Klinikum AG

D-97616 Bad Neustadt a. d. Saale, Von-Guttenberg-Straße 11

E-mail: kaszapb@gmail.com 